УАК 316.7781 .6

ББК 60.55.2 85.31

DOI 10.22394/1682-2358-2017-3-118-123

T.V. Safonova, Candidate of Art History, Docent of the Special Piano Department, Sobinov Saratov State Conservatory

\section{ARTISTIC CREATIVITY IN A SOCIAL CONTEXT}

Mechanisms of interaction between artistic creation and society are considered: the impact of social context on the creation of works of art and mechanisms of its transformation in the space of the inner world of an artist. The structure of the process of Sergei Prokofiev's musical composition is analyzed, and the nature of the social impact of his works is revealed.

Key words and word-combinations. artistic creativity, transformation of social, metaphysical level of creativity, S. Prokofiev.
Т.В. Сафонова, кандидат искусствоведения, доиент кафедрь спечиального фортепиано Саратовской государственной консерватории имени А.В. Собинова (email: tatianasafonova@mail.ru)

\section{ХУАОЖЕСТВЕННОЕ TВОРЧЕСТВО \\ В СОЦИААЬНОМ КОНТЕКСТЕ}

\begin{abstract}
Аннотация. Рассматриваются механизмы взаимодействия художественного творчества и социума: характер воздействия социального контекста на создание произведений искусства и механизмы его трансформации в пространстве внутреннего мира художника. Анализируется структура процесса композиторского творчества С. Прокофьева, выявляется характер социального воздействия его произведений.

Ключевые слова и словосочетания: художественное творчество, трансформации социального, метафизический уровень творчества, С. Прокофьев.
\end{abstract}

ощиальные отношения в обществе, их основания и факторы детерминации представцяют преАмет постоянного внимания ученых, исследующих самые разные аспекты этого направцения гуманитарного знания. ОАнако и в этой обкасти существует ряд проблем, недостаточно разработанных и, в известной мере, отодвинутых на периферию исследовательского пространства, в частности место художественного творчества в структуре социума, его вцияние на формирование общественных отношений. В современную эпоху, когда искусство давно перестало быть сферой, интересующей

118 Bulletin of the Volga Region Institute of Administration • 2017. Vol. 17. № 3 
мишь немногих избранных, благодаря средствам массовой информации, и особенно Интернету, оно стало практически общедоступным, и его влияние на массовое сознание нельзя недоџенивать. Как отмечают исследователи, соџиацьный контекст имплицитно присутствует в цюбом произведении искусства, создавая тем самым неявное поле воздействия [1, с. 46]. Это, в свою очередь, обусловливает актуальность и соџиальную значимость исследований в Аанной области.

Художкественное творчество представцяет собой феномен, природа которого сложна и многогранна. На протяжении столетий преАставления о нем изменялись: от определения искусства как подражания действительности до его трактовки как выражения сверхчувственного. Выявить характер и степень его влияния на область соџиального непросто: оно не происходит прямо и непосреАственно, а осуществляется через сложную цепь взаимосвязей, вкцючающей в том числе и внутренний мир художника. В XX в. искусство обращается к человеку, который теперь явцяется не предметом изображения, а, выражаясь словами одного из авторитетных российских музыковедов В. Медушевского, становится «субъектом «видения»... воплощенным в самом искусстве» [2, с. 83] . Как следствие такого переворота - повышенное внимание к внутренней жизни человеческой души, к исследованию ее глубин, проекция которых осуществляется на внешний мир. Еще в 1910 г. В. Кандинский в работе «О духовном в искусстве» определяет сущность художественного творчества как «внутреннюю душевную необходимость», как погружкение вовнутрь. Избрав в качестве объекта анализа музыкальное искусство, он пишет: «Музыка уже в течение нескольких столетий, за немногими исключениями и отклонениями, явцяется тем искусством, которое пользуется своими средствами не дия изображения явлений природы, а Аля выражения Аушевной жизни музыканта и Аля создания своеобразной жизни музыкальных тонов» [3, с. 37]. При этом глубинное постижение художественного творчества невозможно без выявления соџиальных мотиваций, инициирующих его создание.

Как известно, мюбое произведение искусства в немалой степени определяется особенностями эпохи. К ним относятся общехудожественные универсации и установки, исторический, социальный контекст Аеятельности художника, который становится в той или иной степени неким побуАительным импульсом дия написания произведения. По словам В. Кандинского, «каждый хуАожник, как Аитя своей эпохи, Аолжен выразить то, что присуще этой эпохе» [3, с. 58] . ОАнако соџиокультурная ситуация не транслируется непосреАственно в художкественный текст, но оказывает свое вцияние через мировоззрение и мироощущение автора. «Мотивация текста мироощущением, - подчеркивает С. Кекова, - особый тип мотивации, который раскрывает нам... “молекулярный уровень текста", его “квантовую механику”» [4, с. 13]. Особое значение мироощущения в мотиваџии художественного творчества обнаруживается в процессе анализа таких произведений, которые не могут быть адекватно прочитаны только с позиций внешнего отражения веяний эпохи, их соџиальной обусловценности.

Именно таковым представляется музыкальное наследие С. Прокофьева. 
В советскую эпоху его произведения чаще всего интерпретировацись в свете приверженности композитора идеям соцреализма. Исследователи опирацись в Аанном случае на характерную особенность его музыки - наличие в ней светмого, оптимистического начама, которое бымо присуще Ауху советского искусства. ОАнако в настоящее время данная позиция не может рассматриваться как абсолютно однозначная и бесспорная [5]. Аیя обнаружения подиинной сущности творчества С. Прокофьева и доказательства того, что на протяжении всего творческого пути он следует своим собственным установкам и убеждениям, необходимо обратиться к творческому периоду композитора после его возвращения на Родину.

Политика советского государства в отношении культуры обусловица сосуществование Авух тенденций в искусстве, обусловивших его своеобразное «Авоемирие» [6; 7]. Первая связана с откровенной ориентацией на соџиамистическую идеологию и демонстрирует агитационную направленность творчества. Наряду с этой тенденџией в искусстве существовал и другой пласт, отражающий трагическую сторону Аействующего режима, - присущий ему тотальный страх и полное бесправие, что четко обнаруживается в творчестве таких соџиацьно чутких композиторов, как Н. Мясковский и А. Шостакович. Несмотря на разцичия обеих тенденџий, обе они характеризуются тяготением к «злободневности», к социальной обусловленности идейно-смысловых концепций, что в музыкальном материале проявцяется в присутствии большого числа внемузыкальных идей и символов.

С. Прокофьев занимает в этой ситуации особое место. Аیя него характерна значительная удаленность от соџиально-политических реалий, известная аполитичность, и это отличает его, в частности, от А. Шостаковича, которого А. Шнитке определяет как «сейсмограф действительности». Аюбопытно, что итальянский композитор и педагог $\Lambda$. Ноно ассоџиирует симфонии $\Lambda$. Шостаковича с киномузыкой в духе «соџиалистического реацизма» [8, с. 69]. Известный отечественный музыковеА В. Холопова относит композитора к типу художника-гражданина, тяготеющего к политическим темам в музыке. При всем единстве факторов социокультурной среды деятельности С. Прокофьева и А. Шостаковича в Советской России их творческие портреты различны. С. Прокофьев предстает абсолютно уникацьным явлением, которое не требует какой-либо привязки к контексту, к эпохе или режиму. Безусловно, он не мог обойти заказы, связанные с советской тематикой. Аоказательство этому - его кантата «К 20-летию Октября», «ЗАравица», оперы «Семен Котко», «Повесть о настояшем человеке», оратория «На страже мира». ОАнако Ааже в этих произведениях в полной мере обнаружилось своеобразие композитора, его оригинальный подход, проявившиеся в заметном расхождении музыки и заданного текста. Не отрицая существования отдельных откровенно конформистских произведений, подчеркнем, что С. Прокофьев создает и Аругие работы, в которых, по словам М. Тараканова, «были поставлены и решены с реАкой хуАожественной убедительностью вечные темы, утвердившиеся в европейском искусстве» [9, с. 203]. 
Не вписывается С Прокофьев и в противоположную - «теневую» - тенденцию советского искусства. У композитора отсутствует, по выражению $\Lambda$. Акопяна, «напряженное переживание действительности и подчеркнутая прозаичность» [6, с. 19]), свойственные Ауховной культуре, созданной советской цивилизаџией. Аля него не характерно отражать животрепещущую современность. С. Прокофьев обнаруживает себя как твореџ, тяготеющий к созданию своего уникального мира - в целом гармоничного, но вместе с тем не мишенного инфернальных бездн. В годы политических и социальных катаклизмов (1920-е годы, Вторая мировая война) композитор, словно наперекор всему, обращается к модели волшебной сказки. Считается, что разработка сказочной тематики (в широком понимании) есть Амя композитора не что иное, как способ отстранения от сушествующей действительности, ухоА в мир им^юзий, который явАяется Амя него источником жизненных сим и вдохновения. При ближайшем рассмотрении обнаруживаются более сложные зависимости. Представляется, что в тяготении к сказочности проявцяется не просто стремление С. Прокофьева спрятаться от повседневной жизни, но и нечто большее. В этой отстраненности можно увидеть совершенно отчетливую позицию художника, сознательно дистанцирующегося от исторической, существуюшей действительности и погруженного в мир вечных ценностей. Это не уход от реальности, а выявление в ней вечных, вневременных идей с конџентраџией именно на этих уровнях бытия, называемых метафизическими. Именно это - надвременное, общечеловеческое - в силу своей апемляџии к вечному, способно оказывать существенное вмияние как на современников, так и на последующие поколения, затрагивая глубинные пласты человеческой мичности.

Определяя метафизический уровень как «элемент чисто и вечно художественного», М. Кандинский называет его третьим эмементом художественного творчества. По словам автора, он «проходит через всех цюдей, через все национальности и через все времена; этот элемент можно видеть в художественном произведении каждого художника, каждого народа и каждой эпохи; как главный элемент искусства он не знает ни пространства, ни времени» [3, с. 58]. Со временем, отмечает В. Кандинский, значение этой составмяюшей возрастает, обусловливая тем самым величие художника.

В своем творчестве С. Прокофьев уходит от обыденности, он словно существует в Аругом измерении - мире самой музыки. Композитора отмичает индифферентное отношение к изображению всего того, что не явмяется собственно музыкой. По словам А. Горбатова, «музыка Прокофьева отвечает основному эстетическому критерию не только “новой музыки", но и музыки прошлых эпох, а именно: все то, из чего состоит музыка Прокофьева, и есть ее содержание. Аия того чтобы понимать его музыку, вовсе не нужно быть советским человеком - надо просто знать и мюбить музыку вообще» [10] .

Творчество давало возможность композитору дистанцироваться от реальности, погрузиться в иное, собственно музыкальное бытие. Этой установке он следовал всегда и везде, независимо от его местопребывания - в России 
или за рубежом. Об этом свидетельствует и анализ биографических данных композитора в годы его пребывания в СССР. Известно, что С. Прокофьев вполне осознавал политическую ситуацию в стране и сознательно занимац позицию невмешательства, чувствуя негативные последствия, которые могли бы помешать его музыкальной деятельности. «В моем представлении музыка и политика взаимно отталкиваются» [11, с. 90], - писал он 12 сентября 1929 г. В. Аержановскому. Как показывают свидетельства Аюдей, знавших С. Прокофьева и получивших возможность поделиться своими наблюдениями в эпоху гласности, он вовсе не был слеп и глух к тому, что происходило в его стране, он не мог не знать о трагической судьбе В. Мейерхольда и ряда Аругих деятемей художкественного мира, объявленных врагами народа. ОАнако композитор еще в годы скитаний за рубежом занял позищию полного невмешательства в политику, тщательно избегая высказываний на темы, не имеющие прямого отношения к музыке.

Великий композитор, конечно, знал правду о своем времени и адекватно осознавац все перипетии эпохи. ОАнако особое значение Амя его натуры имела нейтрализаџия и вытеснение на периферию сознания всех негативных аспектов жизни. Внешние обстоятельства не могли разрушить те внутренние, прочно заложенные с детства основы, которые выражались в осознанном следовании композитора миру абсолютных ценностей и в его внутренней устремленности к гармонии и свету. Эти основы явцялись прочным фундаментом, внутренним стержнем цичности С. Прокофьева на протяжении всего его жизненного пути. Они весьма важны и Аля понимания особенностей его натуры. Тщательно оберегаемый С. Прокофьевым от внешних влияний внутренний мир, ориентированный на идеалы красоты, добра и гармонии, был Аля художника приоритетнее, чем сиюминутный эмоџиональный отклик на «вызовы» эпохи.

В этом свете представмяется правомерной и весьма значимой проведенная А. Цукером парамлель межау С. Прокофьевым и В. Моцартом: «Аля обоих композиторов художественное творчество было истинной, исконнейшей формой их существования, а искусство в куда большей мере становилось содержанием их жизни, чем наоборот. Их искусство мало нуждалось в каких-либо реальных жизненных импульсах и, в известном смысле, было самодостаточным. Оба художника вольно и независимо созидали свой мир, свободный от законов и ограничений, кроме тех, которые они сами Аля себя устанавливали» $[12$, c. 200] .

Именно эта особенность - интериоризаџия сощиального, его импликаџия в структуру внутреннего мира - делает художника соџиально значимым, обусловливает его включение в число наиболее выдающихся представителей человечества, оказавших сушественное влияние на его развитие.

\section{Библиографический список}

1. Фомина 3. Проблема патриотизма в художественной рефлексии // Консервативные традиции и либеральные ценности в постсоциалистической России: сборник научных статей. Саратов, 2016. С. 46-49. 
2. Медушевский В. Художественная картина мира в музыке (к анализу понятия) // Художественное творчество. Вопросы комплексного изучения. Л., 1986.

3. Кандинский В. О духовном в искусстве. М., 1992.

4. Кекова С. Мироощущение Николая Заболоцкого: опыт реконструкции и интерпретации. Саратов, 2007.

5. Сафонова Т.В. Метафизическая составляющая в творчестве С.С. Прокофьева. Саратов, 2011.

6. Акопян Л. Дмитрий Шостакович: опыт феноменологии творчества. СПб., 2004.

7. Долинская Е. Прокофьев и Мясковский // Московский музыковед. М., 1991. Вып. 2.

8. Ноно Л. Автобиография (Фрагменты интервью с Э. Рестаньо) // XX век. Зарубежная музыка: очерки и документы. М., 1995. Вып. 2.

9. Тараканов М. Прокофьев: многообразие художественного сознания // Русская музыка и ХХ век. М., 1998.

10. Горбатов Д. Накануне нового тысячелетия: Размышление о Шостаковиче в рамках проблем общей музыкальной эстетики. URL: http://www. lebed. com/2000/art2336.

11. Кремлев Ю. Эстетические взгляды С. Прокофьева: по материалам высказываний. М.; Л., 1966.

12. Цукер А. Моцарт - Прокофьев: традиция и судьба // Цукер А. Единый мир музыки: избранные статьи. Ростов н/Д, 2003. 